\title{
A Study of Linkage Effects and Environmental Impacts on Information and Communications Technology Industry between South Korea and USA: 2006-2015
}

\author{
Junhwan Mun ${ }^{1} \mathbb{D}$, Eungyeong Yun ${ }^{2}$ and Hangsok Choi ${ }^{3, *}$ \\ 1 Department of Convergence Program for Social Innovation, Sungkyunkwan University, Seoul 03063, Korea; \\ mjhpioneer@skku.edu \\ 2 Department of Business Consulting, Meta Credit Group Consulting, Seoul 07299, Korea; \\ egyun@mcgcorp.co.kr \\ 3 Department of Business Administration, Dongduk Women's University, Seoul 02748, Korea \\ * Correspondence: hschoi918@dongduk.ac.kr
}

Citation: Mun, J.; Yun, E.; Choi, H. A Study of Linkage Effects and Environmental Impacts on Information and Communications Technology Industry between South Korea and USA: 2006-2015. Processes 2021, 9, 1043. https://doi.org/10.3390/ pr9061043

Received: 1 April 2021

Accepted: 9 June 2021

Published: 15 June 2021

Publisher's Note: MDPI stays neutral with regard to jurisdictional claims in published maps and institutional affiliations.

Copyright: (c) 2021 by the authors. Licensee MDPI, Basel, Switzerland. This article is an open access article distributed under the terms and conditions of the Creative Commons Attribution (CC BY) license (https:// creativecommons.org/licenses/by/ $4.0 /)$.

\begin{abstract}
This study examined the relationship among carbon dioxide emissions and linkage effects using Input-Output (IO) data of the information and communications technology (ICT) industry between South Korea and the USA. As we wanted to find out if the ICT industry, which the world is passionate about, is a sustainable industry. The linkage effects are analyzed to determine the impact of ICT industry on the national economy, and $\mathrm{CO}_{2}$ emissions of the industry are analyzed to determine how much influence it has on air pollution. In addition, we classify ICT industry by ICT service and manufacturing industries as the key industries in Korea and the US. Data were collected from OECD ranging from 2006 to 2015 in order to quantitatively estimate backward linkage, forward linkage effect, and carbon dioxide emissions. The results indicated that ICT manufacturing industry in Korea has high backward and forward linkage effects. $\mathrm{CO}_{2}$ emissions from ICT service is more than from ICT manufacturing in both Korea and the US. We wanted to find out if the ICT industry, which the world is passionate about, is a sustainable industry. As a contribution, ICT manufacturing and service industries in Korea and the United States are directly compared, and $\mathrm{CO}_{2}$ emissions over 10 years are analyzed in a time series.
\end{abstract}

Keywords: IO analysis; $\mathrm{CO}_{2}$ emission; ICT service; ICT manufacturing

\section{Introduction}

Global warming is the most serious problem facing humankind today. It is because, due to human activities, greenhouse gases (GHG) are increasing at an unprecedented rate and are accumulating in the atmosphere. Such global warming raises the global temperature, leading to abnormal weather conditions and destruction of ecosystems, and it will soon affect a wide range of areas beyond them, from energy supply to human health. The necessity of reducing GHG for the survival of humankind has become an important agenda of the international community. Korea is a country that emits many greenhouse gases. However, in order to become a country responsible for reducing greenhouse gas emissions and responding to climate change in the international community, Korea has presented a challenging goal of reducing business as usual (BAU) by 37\% by 2030 [1]. Low carbon and GHG reduction are becoming a target not only for Korea, but also for countries around the world. The key strategies for low carbon in major countries are summarized in energy efficiency improvement, energy conversion, and resource circulation. [2]. First, they set up a strategy to reduce production costs and reduce greenhouse gas emissions by increasing energy efficiency and reducing energy consumption. In addition, they seek sustainable growth by replacing final energy consumption in industries with clean energy such as fossils, electricity, and renewable energy, and they strive to build a resource recycling economy system that reuses and recycles resources in industrial processes that emit large 
amounts of greenhouse gases. The Korean government creates the foundation necessary for low-carbon and green growth for the harmonious development of the economy and environment. They attempt to promote the national economy development by using green technology and green industry as new growth engines. Furthermore, Korea aims to improve the quality of life of people by building low-carbon society and to leap forward as a mature advanced country that fulfills its responsibilities in the international community [3]. To this end, the first step begins with reducing greenhouse gas emissions. Additionally, it is necessary to focus on securing innovative technologies such as developing low-carbon fuel processes and air pollution reduction facilities, while preparing a specific roadmap for the stable supply of green hydrogen and green energy and formation of an appropriate price. However, since Korea has an industrial structure different from those of countries that are strongly pursuing low carbon, their domestic reality should be considered.

Table 1 shows share of added value in ICT industry in 4 countries and the average of OECD. Korea has the world's best network infrastructure built and distributed and has a favorable environment for developing the Fourth Industry such as Internet of Things, autonomous vehicles, and Big Data analysis. However, the information and communication technology (ICT) industry in Korea is more concentrated in the ICT manufacturing sector than in other countries [4]. Thus, software and ICT service sector is inferior to countries such as the United States and Japan. Despite the high share of added value in ICT manufacturing industry, the share of the ICT service industry is below the OECD average [5].

Table 1. Share of added value to GDP in the ICT industry (2015).

\begin{tabular}{ccccc}
\hline Country & ICT Manufacturing & Communication & $\begin{array}{c}\text { Software } \\
\text { and Service }\end{array}$ & $\begin{array}{c}\text { Sum of ICT } \\
\text { Industrial }\end{array}$ \\
\hline Korea & $5.6 \%$ & $1.0 \%$ & $1.6 \%$ & $8.2 \%$ \\
USA & $1.5 \%$ & $1.5 \%$ & $2.1 \%$ & $5.1 \%$ \\
EU & $0.8 \%$ & $1.2 \%$ & $2.0 \%$ & $4.0 \%$ \\
Japan & $1.7 \%$ & $1.9 \%$ & $2.4 \%$ & $6.1 \%$ \\
Average of OECD & $1.0 \%$ & $1.2 \%$ & $1.9 \%$ & $4.1 \%$ \\
\hline
\end{tabular}

Source: Authors' own calculations on the data form [5], 'OECD digital outlook 2017', based on 2015 data; comparison of EU (23 country's) and OECD (33 country's).

However, the growth of ICT manufacturing industry in Korea, which is so strong, has slowed over the past five years. Its growth rate fell sharply from 50\% in 2010 to - 9\% in 2015, but in the United States it fell from 10\% in 2010 to 5\% in 2014 [6]. Moreover, Korea is the second country in the world with the highest proportion of manufacturing to GDP after China [7]. On the other hand, the proportion of the service industry is lower than that of the US, the UK, and France [7]. The growth rate of ICT service industry in Korea was around 5\% in 2011, but it has since declined. The growth rate of ICT service industry in the US fell sharply from $10 \%$ in 2012 to $-5 \%$ in 2013 . However, in 2014, it turned to a positive growth rate of $4 \%$ [6]. As such, it is appropriate to analyze ICT industry by categorizing it into manufacturing and service sectors because the growth rate and major powerhouses differ according to the type of final product. Additionally, this also helps in establishing a low-carbon strategy.

$\mathrm{CO}_{2}$ emissions in ICT industry are included not only from the electricity consumed in the use of products and devices, but also from the energy used in the products. Ericsson [8] largely categorizes $\mathrm{CO}_{2}$ emissions of ICT industry into user devices, networks, and data centers in consideration of these points. Since $\mathrm{CO}_{2}$ emissions are different for each sector, applying low-carbon strategy of countries with a high proportion of the service industry may be a strategy that does not take into account the specificity of the industrial structure of a country that is strong in the manufacturing industry. The active national-level response to overcome the limit of reducing $\mathrm{CO}_{2}$ emissions should be implemented in a flexible environment according to the industrial sector.

According to a study by Belkhir and Elmeligi [9], by 2040 if the carbon emission of the ICT industry remains as it is, it will account for up to $14 \%$ of the global carbon emission. In addition, countries around the world are actively working to strengthen industrial 
competitiveness using ICT technology. Therefore, we want to understand how much ICT industry has an impact on $\mathrm{CO}_{2}$ emissions in a country in this study as it is becoming more and more important.

Although it is focusing on the development of industries related to the fourth industry such as Artificial Intelligence, Big Data, and autonomous vehicles, it is questionable whether these industries can be said to be eco-friendly and sustainable industries that can grow with other industries together. In other words, the research questions of this study were:

1. We confirmed that ICT industry in the US and Korea was a sustainable industry.

2. We checked whether there was a difference in the influence of the manufacturing sector and the service sector of ICT industry on the national economy.

We selected input-output analysis as the theoretical method, and compared changes in ICT manufacturing and ICT service industries in the US and Korea. We also compared $\mathrm{CO}_{2}$ emissions of the two countries. To be a sustainable industry, we needed to make sure that the industry pollutes the air less. The United States has the world's highest sales and industry share of ICT industry and has the largest number of companies in ICT service among the global representative digital companies [10]. We think it is important to compare and analyze the connection between $\mathrm{CO}_{2}$ emissions and linkage effects in ICT manufacturing industry in Korea and ICT service industry in the United States. This is because the world wants to foster industries with low carbon dioxide emissions and high productivity. In order to discover a sustainable industry in this future as we have mentioned, we will derive $\mathrm{CO}_{2}$ emissions from ICT manufacturing and ICT service industries in Korea and the US from 2006 to 2015, and analyze backward and forward linkage effects. After analysis, we will present the direction of low-carbon development that suits the conditions of each country.

This study is organized as follows. Section 2 introduces the importance of $\mathrm{CO}_{2}$ emissions research and previous studies related to ICT manufacturing and ICT service and establishes hypotheses. Then, Section 3 explains research methods and data. In Section 4, we describe the results of the analysis. Finally, in Section 5, policy suggestions are made through analysis of the results

\section{Literature Review and Hypotheses Development}

According to the OECD, ICT (Information and Communications Technology) industry is defined as the production of goods and services products that are primarily used to represent information processing and communication and transmission by electronic means. ICT industry can be divided into ICT manufacturing and ICT service business, and in detail, it can be classified into computer parts, electronic and electrical equipment manufacturing, information and communication related business, and software business [11]. Table 2 shows the definition of each ICT industry. In 1998, OECD member countries agreed to define the ICT sector as a combination of manufacturing and services industries that capture, transmit, and display data and information electronically [12].

Table 2. Definition of ICT manufacturing and service industries.

\begin{tabular}{cl}
\hline Sector & \multicolumn{1}{c}{ The Principles Underlying the Definition } \\
\hline ICT & - Must be intended to fulfil the function of information processing and \\
manufacturing & communication including transmission and display. \\
Industry & $\begin{array}{l}\text { Must use electronic processing to detect, measure, and /or record } \\
\text { physical phenomena or control a physical process. }\end{array}$ \\
ICT & - Must be intended to enable the function of information processing and \\
service & communication by electronic means. \\
Industry &
\end{tabular}

However, there was a debate about the principle of selecting the ICT industry and the interpretation of the principle in 1998. As a result, the definition of ICT industry 
classified ICT industry by adding a section called ICT trade. Table 3 shows a list of industries belonging to ICT industry according to the 4th International Standard Industry Classification (ISIC).

Table 3. The list of ICT industries (ISIC Rev. 4).

\begin{tabular}{ccc}
\hline Sector & & ISIC Rev. 4 (2007) \\
\hline & 2610 & Manufacture of electronic components and boards \\
ICT & 2620 & Manufacture of computers and peripheral equipment \\
Manufacturing & 2630 & Manufacture of communication equipment \\
& 2640 & Manufacture of consumer electronics \\
ICT Trade & 2680 & Manufacture of magnetic and optical media \\
& 4651 & Wholesale of computers, computer peripheral equipment, and software \\
& 5852 & Wholesale of electronic and telecommunications equipment and parts \\
ICT Services & 6110 & Software publishing \\
& 6120 & Telecommunications \\
& 6130 & Wired telecommunications activities \\
& 6190 & Wireless telecommunications activities \\
& & Satellite telecommunications activities \\
& & Other telecommunications activities \\
\hline
\end{tabular}

Meanwhile, the OECD continued to work on the definition and classification system for the content media industry based on the prospect that structural changes that would occur in the content production and distribution industry as the number of content users increases due to the spread of ICT technology. Additionally, this was reflected in ISIC revision 4 . When transitioning from ISIC revision 3 to ISIC revision 4 , they included the production and distribution of information and cultural products, information technology and data processing, and information service activities. ISIC revision 4 classifies the information and communication service sector into one section and classifies the ICT industry as Table 4 [13].

Table 4. The 2006-2007 OECD ICT sector definition (based on ISIC Rev. 4).

\begin{tabular}{ccc}
\hline Sector & & ISIC Rev. 4 (2008) \\
\hline & 2610 & Manufacture of electronic components and boards \\
ICT & 2620 & Manufacture of computers and peripheral equipment \\
Manufacturing & 2630 & Manufacture of communication equipment \\
& 2640 & Manufacture of consumer electronics \\
& 2680 & Manufacture of magnetic and optical media \\
& 5820 & Software publishing \\
& 6110 & Wired telecommunications activities \\
& 6120 & Wireless telecommunications activities \\
& 6130 & Satellite telecommunications activities \\
& 6190 & Other telecommunications activities \\
& 6201 & Computer programming activities ICT \\
& 6202 & Computer consultancy and computer facilities management \\
& 6209 & activities ICT \\
& 6311 & Other information technology and computer service activities \\
& 6312 & Data processing, hosting, and related activities \\
& & Web portals
\end{tabular}

There is a slight difference in whether detailed enterprise groups should be included in ICT manufacturing industry or ICT service industry by era, but as a result, it shows consistency in classifying ICT industry into ICT manufacturing industry and service industry. According to Global Industry Classification Standard, S\&P capital IQ industry classification, ICT industry is classified into Semiconductors \& Semiconductor Equipment industries, Technology Hardware \& Equipment (ICT manufacturing), and Software \& Services industries and industries related to digital technology such as IoT, fifth generation technology standard, cloud, big data, and AI software are evaluated as key drivers of the fourth industrial revolution.

Several researchers have also divided ICT industry into the manufacturing sector and the service to study their impact on the national economy as Table 5 [14-17]. 
Table 5. Research on ICT industry divided into manufacturing and service sectors.

\begin{tabular}{|c|c|c|c|}
\hline Researcher & Country & Year & Aim of the Study \\
\hline Xing et al. (2011) & China & 2002 & $\begin{array}{l}\text { Analyzing the form of convergence between ICT } \\
\text { manufacturing industry and ICT service industry, and } \\
\text { identifying their role }\end{array}$ \\
\hline Rohman (2013) & EU & 1995, 2000, 2005 & $\begin{array}{l}\text { Analyzing the strengths of ICT industry by comparing the } \\
\text { multiplier effects of ICT industry and non-ICT industry. }\end{array}$ \\
\hline $\begin{array}{l}\text { Hong, J.P., Byun, J.E., } \\
\text { and Kim, P.R. (2016) }\end{array}$ & Korea & From 1995 to 2009 & $\begin{array}{l}\text { Examining structural changes and growth factors of ICT } \\
\text { manufacturing and service industries }\end{array}$ \\
\hline $\begin{array}{l}\text { Abubakar, Y.A., and } \\
\text { Mitra, J. (2010) }\end{array}$ & EU & From 2001 to 2003 & $\begin{array}{l}\text { Investigating factors influencing regional innovation by } \\
\text { contrasting high-tech manufacturing (ICT manufacturing) } \\
\text { and knowledge intensive services (ICT service) }\end{array}$ \\
\hline
\end{tabular}

Korea commercialized 5G, the basic infrastructure of the 4IR, for the first time in the world. Currently, 24 countries have commercialized 5G or are planning to do so, and Korea is evaluated as a world leader in $5 \mathrm{G}$ commercialization [18]. In addition, they have a well-distributed ICT infrastructure, excellent accessibility, and a favorable environment for responding to technology related to the fourth industry. The global cloud market is worth USD 243 trillion [19], and the top three global companies (Amazon, Microsoft, Google) account for $57 \%$ of the market [20]. American companies already dominated more than half of global ICT service market (as of 2018) [21]. By comparison, Korean Cloud market is USD 2 billion, which is only $1 \%$ of the world market. ICT industry in Korea is more concentrated in the manufacturing sector than in other countries, so the software and ICT service sectors are inferior to rival countries such as the United States and Japan [5].

Table 6 shows the R\&D investment status of major countries by industry in 2019. Of the 2500 companies, there are a total of 70 Korean companies, and they invested about USD 3.67 billion in R\&D budget for a year [22]. Among them, 16 ICT manufacturing industries invested about USD 24.95 billion, and five ICT service industries invested USD 846 million. This means that $70.2 \%$ of the R\&D budget of Korean companies is invested in ICT manufacturing and ICT service industries. The US has the highest R\&D investment ratio in ICT manufacturing and ICT service industries, and Korea has the lowest investment ratio in ICT service industry at $0.6 \%$ compared to other countries. While the US invests intensively in ICT service, ICT manufacturing, and health industries, Korea is excessively focused on ICT manufacturing. Therefore, it is necessary to promote the future development of Korea by expanding investment in ICT service industry as the ICT service industry is an important sector that connects various industries in the new era [23].

Table 6. R\&D investment by industry and share by country (2019).

\begin{tabular}{|c|c|c|c|c|c|c|c|}
\hline Country & Korea & EU & USA & Japan & China & Other & Total \\
\hline $\begin{array}{c}\text { ICT } \\
\text { Manufacturing }\end{array}$ & $\begin{array}{l}277068 \\
(10.9 \%)\end{array}$ & $\begin{array}{l}350194 \\
(13.8 \%)\end{array}$ & $\begin{array}{l}1039653 \\
(40.9 \%)\end{array}$ & $\begin{array}{l}282468 \\
(11.1 \%)\end{array}$ & $\begin{array}{l}369681 \\
(14.6 \%)\end{array}$ & $\begin{array}{l}220856 \\
(8.7 \%)\end{array}$ & $\begin{array}{l}2539921 \\
(100 \%)\end{array}$ \\
\hline ICT Service & $\begin{array}{l}9396 \\
(0.6 \%)\end{array}$ & $\begin{array}{l}192305 \\
(11.6 \%)\end{array}$ & $\begin{array}{l}1111437 \\
(67.1 \%)\end{array}$ & $\begin{array}{l}68112 \\
(4.1 \%)\end{array}$ & $\begin{array}{l}222116 \\
(13.4 \%)\end{array}$ & $\begin{array}{l}85530 \\
(3.2 \%)\end{array}$ & $\begin{array}{c}1655896 \\
(100 \%)\end{array}$ \\
\hline Health & $\begin{array}{l}8362 \\
(0.4 \%)\end{array}$ & $\begin{array}{l}591757 \\
(26.6 \%)\end{array}$ & $\begin{array}{l}1089259 \\
(49.0 \%)\end{array}$ & $\begin{array}{l}172388 \\
(7.8 \%)\end{array}$ & $\begin{array}{l}60838 \\
(2.7 \%)\end{array}$ & $\begin{array}{l}300892 \\
(13.5 \%)\end{array}$ & $\begin{array}{l}2223497 \\
(100 \%)\end{array}$ \\
\hline $\begin{array}{l}\text { Manufacture of motor } \\
\text { vehicles and transportation }\end{array}$ & $\begin{array}{l}56601 \\
(3.4 \%)\end{array}$ & $\begin{array}{l}795317 \\
(47.7 \%)\end{array}$ & $\begin{array}{l}240605 \\
(14.4 \%)\end{array}$ & $\begin{array}{l}424664 \\
(25.5 \%)\end{array}$ & $\begin{array}{l}110945 \\
(6.7 \%)\end{array}$ & $\begin{array}{l}39552 \\
(2.4 \%)\end{array}$ & $\begin{array}{c}1667684 \\
(100 \%)\end{array}$ \\
\hline (manufacturing) industry & $\begin{array}{l}30992 \\
(4.0 \%)\end{array}$ & $\begin{array}{l}206451 \\
(26.9 \%)\end{array}$ & $\begin{array}{l}188392 \\
(24.6 \%)\end{array}$ & $\begin{array}{l}144571 \\
(18.9 \%)\end{array}$ & $\begin{array}{l}149339 \\
(19.5 \%)\end{array}$ & $\begin{array}{l}46685 \\
(6.1 \%)\end{array}$ & $\begin{array}{l}766430 \\
(100 \%)\end{array}$ \\
\hline Chemical industry & $\begin{array}{l}3687 \\
(1.3 \%)\end{array}$ & $\begin{array}{c}68402 \\
(23.3 \%)\end{array}$ & $\begin{array}{l}65787 \\
(22.4 \%)\end{array}$ & $\begin{array}{c}99087 \\
(33.8 \%)\end{array}$ & $\begin{array}{l}19540 \\
(6.7 \%)\end{array}$ & $\begin{array}{c}36859 \\
(12.6 \%)\end{array}$ & $\begin{array}{l}293362 \\
(100 \%)\end{array}$ \\
\hline $\begin{array}{c}\text { Aerospace and Defense } \\
\text { industry }\end{array}$ & $\begin{array}{c}4074 \\
(1.5 \%)\end{array}$ & $\begin{array}{l}120838 \\
(45.8 \%)\end{array}$ & $\begin{array}{l}109282 \\
(41.5 \%)\end{array}$ & $(0.0 \%)$ & $\begin{array}{c}4331 \\
(1.6 \%)\end{array}$ & $\begin{array}{l}25049 \\
(9.5 \%)\end{array}$ & $\begin{array}{l}263574 \\
(100 \%)\end{array}$ \\
\hline Other & $\begin{array}{l}17839 \\
(1.3 \%)\end{array}$ & $\begin{array}{l}393693 \\
(29.5 \%)\end{array}$ & $\begin{array}{c}233973 \\
(17.5 \%)\end{array}$ & $\begin{array}{c}236951 \\
(17.7 \%)\end{array}$ & $\begin{array}{l}321055 \\
(24.0 \%)\end{array}$ & $\begin{array}{l}131807 \\
(9.9 \%)\end{array}$ & $\begin{array}{c}1335318 \\
(100 \%)\end{array}$ \\
\hline Total & $\begin{array}{l}408019 \\
(3.8 \%)\end{array}$ & $\begin{array}{l}2718957 \\
(25.3 \%)\end{array}$ & $\begin{array}{l}4078388 \\
(38.0 \%)\end{array}$ & $\begin{array}{l}1428242 \\
(13.3 \%)\end{array}$ & $\begin{array}{l}1257847 \\
(11.7 \%)\end{array}$ & $\begin{array}{l}854230 \\
(7.9 \%)\end{array}$ & $\begin{array}{c}10745683 \\
(100 \%)\end{array}$ \\
\hline
\end{tabular}


As is well known, ICT industry is the future food of not only Korea and the United States, but also major countries. Moreover, low carbon and greenhouse gas emission reduction policies are also being implemented for the future. The US announced 2013 Climate Action Plan, reducing carbon emissions and leading international community's efforts to respond to climate change [25]. In China, $\mathrm{CO}_{2}$ emissions once increased by 15-17\%/year due to rapid economic growth but based on the "National Plan for Response to Climate Change (2013-2020)," they are pushing for reduction of emissions and changes in energy mix [3].

In order to simultaneously foster sustainable development and the development of the future food, the ICT industry, $\mathrm{CO}_{2}$ emissions of ICT industry should be lower than that of other industries, and economic linkage effect should be high. After the collapse of the dot-com bubble in 2000, research in the ICT industry shifted to industrial analysis. As a result, it has been expanded to the academic doctrine that ICT industry serves as a driving force for innovation and a catalyst for innovation [26,27].

ICT industry has the power to induce innovation and speed up the innovation of companies. It can also penetrate the economy as a whole, affect all industries, and cause a technology shock [27]. Mas, de Guevara [28] find that all of them experienced growth in the ICT sector. In OECD countries, the ICT sector's share in GDP has remained relatively constant since 1995, implying a growth in total value added as GDP has also grown in that time [5,11,29]. Mattioli and Lamonica [30] classified linkage effects of the ICT industry in the overall economy, and said that ICT industry had a low backward linkage effect and a high forward linkage effect, resulting in a strong supply side to the industry as a whole. As such, it is the ICT industry that has a large linkage effect on the national economy [16,30-34].

However, if the ICT industry is the industry that causes environmental pollution due to high $\mathrm{CO}_{2}$ emissions, then the ICT industry cannot be said to be a sustainable industry. Therefore, many researchers are continuing research to measure $\mathrm{CO}_{2}$ emissions of each country and $\mathrm{CO}_{2}$ emissions of major industries in order to find industries with less environmental pollution [33,35-39]. Loefgren and Muller [35] studied the relationship between energy use efficiency and carbon emissions and suggested a plan to improve carbon emission efficiency as an effective method to reduce carbon emission. Zhou et al. [36] used DEA to estimate the $\mathrm{CO}_{2}$ emission efficiency of OECD countries. Jaeger et al. [39] concluded that low-carbon-based growth is optimistic for economic growth and job creation in their research Lee et al. [38] conducted a study to measure the productivity of the Korean manufacturing industry based on $\mathrm{CO}_{2}$ emissions. Moon et al. [37] analyzed linkage effects of all Korean industries from 2005 to 2015 in a time series to derive eco-friendly industries with high linkage effects.

As ICT industry is highly competitive, air pollution reduction measures such as carbon emissions management are needed to become a sustainable industry. Therefore, we would like to examine the relationship between linkage effect and $\mathrm{CO}_{2}$ emissions of ICT industry. In addition to service-based intangible industries such as big data and artificial intelligence, the ICT industry also includes hardware manufacturing industries such as semiconductors and automobiles. In addition to service-based intangible industries such as big data and artificial intelligence, the ICT industry also includes hardware manufacturing industries such as semiconductors and automobiles. There are a number of studies comparing the impact of the ICT industry on the national economy and the productivity performance of the ICT industry $[27,31,32,40,41]$, but few studies have classified the ICT industry into manufacturing and service industries [34,42]. There are not many studies comparing the ICT industry between Korea and the United States [43,44], either. However, depending on the shape of final product, the influence on other industries or the influence from other industries may differ. Therefore, we will analyze linkage effect and $\mathrm{CO}_{2}$ emissions of each industry by dividing ICT industry into ICT-Service and ICT-Manufacturing sector according to International Standard Industry Classification from OECD. Additionally, to test the difference, we developed hypotheses as Table 7. 
Table 7. Statistical Hypotheses of the Regression Model.

\begin{tabular}{|c|c|}
\hline \multicolumn{2}{|r|}{ Hypotheses } \\
\hline H1 & The linkage effect between Korean ICT manufacturing industry and the US one is different. \\
\hline H1a & $\begin{array}{l}\text { The backward linkage effect between the Korean ICT manufacturing industry and the US } \\
\text { one is different. }\end{array}$ \\
\hline H1b & $\begin{array}{l}\text { The forward linkage effect between the Korean ICT manufacturing industry and the US } \\
\text { one is different. }\end{array}$ \\
\hline $\mathbf{H} 2$ & The linkage effect between Korean ICT service industry and the US one is different. \\
\hline $\mathrm{H} 2 \mathrm{a}$ & The backward linkage effect between the Korean ICT service industry and the US one is different. \\
\hline $\mathrm{H} 2 \mathrm{~b}$ & The forward linkage effect between the Korean ICT service industry and the US one is different. \\
\hline
\end{tabular}

\section{Materials and Methods}

This study uses IO tables from Korea and the United States provided by the OECD for 10 times from 2006 to 2015 [45]. ICT industry was divided into ICT manufacturing and service industry according to the fourth International Standard Industry Classification. $\mathrm{CO}_{2}$ emissions are based on $\mathrm{CO}_{2}$ emissions embodied in domestic final demand provided by the OECD from 2006 to 2015 [45]. This is because when analyzing linkage effects, it is analyzed as domestic production, so that $\mathrm{CO}_{2}$ emissions must also be analyzed as occurring in the domestic production process to enable an accurate comparison [37]. When analyzing $\mathrm{CO}_{2}$ emissions of ICT industry, the same industry classification standard as in the analysis of the linkage effects is applied to determine whether there is a difference in $\mathrm{CO}_{2}$ emissions depending on the final output type.

Linkage effects suggested by Hirschman [46] are to derive the production induction coefficient using the IO table, and to indicate the degree of industrial activation through the derived production induction coefficient. Linkage effects of Hirschman [46] is that an industry induces production directly or indirectly to all industries within a country, and the degree is expressed as production induction coefficient. It can be said that the greater the production inducement coefficient, the greater the power to revitalize the entire industry. The linkage effects can be divided into backward linkage effect and forward linkage effect.

Backward linkage effect can be expressed as the pulling power that induces the input of intermediate goods in the process of an industry producing final goods [47]. In other words, the backward linkage effect is the power of dispersion because one industry induces production to other industries through demand for intermediate goods in the process of producing final goods, and the production inducement continuously promotes production to others $[48,49]$. The high coefficient means that it has strengths as a "demander" in the national economy [27].

Forward linkage effect is a production inducing effect that occurs when the final goods of one industry are input as intermediate goods of other industries. Forward linkage effect is explained as an interaction that directly triggers the structural relationship between supply and demand for intermediate goods across the industry as a business client inputs a product [47]. It is also explained by the reaction that occurs when the entire national industry is activated, the sensitivity of dispersion, and the effect of inducing supply [30,48-50]. The high value of this coefficient can be said to be a strength as a "supplier" in the national economy [27].

To explain these effects with a formula, we use the production inducement effect matrix, which is created based on the IO table that presents the transaction figures between industries in a certain form is used. IO table shows the interdependence of goods and services between industries, the input of production factors, and the sales process according to the final demand of products. The horizontal direction represents the sales breakdown of products in each industry and consists of intermediate demand sold as intermediate goods and final demand sold as consumer goods, capital goods, and exports. Additionally, here, excluding income becomes the total output. The vertical direction shows the input structure of each industry, and it can be divided into intermediate inputs of raw materials and value-added inputs such as labor and capital, and the total is the total input amount. 
The effect on production inducement is the direct or indirect production fluctuations caused by the final demand through the input coefficient.

The concept of the effect on production inducement was proposed by Leontief [51] based on Keynesian multiplier theory. The effect on production inducement by the direct production factor can be expressed as follows.

$$
(1-a)^{-1}=\frac{1}{1-a}=1+a+a^{2}+a^{3}+\ldots
$$

where 1 is the direct production factor, $a$ is the primary effect on production inducement, and $a^{2}$ is the secondary effect on production inducement. Therefore, the effect on production inducement is expressed as the sum of infinite geometric series of $(1-a)^{-1}$ when $a$ is $0<a<1$. With this logic, the production induction coefficient can be obtained through the inverse matrix $(I-A)^{-1}$ of $A$, which is the matrix of $a_{i j}$, and this is called Leontief inverse matrix.

$$
(I-A)^{-1}=I+A+A^{2}+A^{3}+A^{4}+\ldots \ldots
$$

$I$ on the right side represents the direct production effect of each industry to satisfy the final demand for each industry's product of by one unit. $A$ is the primary production inducement effect, which is the input unit of intermediate goods necessary for the production of final goods in each industry. $A^{2}$, the secondary production inducement effect, is the unit of input of intermediate goods required for the production of each industry as a result of the primary production inducement effect and $A^{3}, A^{4}, \ldots \ldots$ are the $3 \mathrm{rd}, 4 \mathrm{th}, \ldots \ldots$ production inducement effect. Therefore, $(I-A)^{-1}$ means the production inducement coefficient, which is the sum of the direct and indirect production inducement effects caused by an increase in final demand by one unit. Since the production inducement coefficient has the property of a multiplier representing the inducement effect derived from the final demand for an industry.

The linkage effect is the theory suggested by Rasmussen [52] and Hirschman [46]. If the element of the production inducement matrix is $r_{i j}$ and the Leontief inverse matrix, $(I-A)^{-1}$, is changed to $\sum_{i} B_{i j}$, the backward linkage effect and forward linkage effect can be expressed as follows [53].

$$
\begin{aligned}
F L_{i} & =\frac{\sum_{j=1}^{n} r_{i j}}{\frac{1}{n} \sum_{i=1}^{n} r_{i j} \sum_{j=1}^{n} r_{i j}} \\
B L_{i} & =\frac{\sum_{i=1}^{n} r_{i j}}{\frac{1}{n} \sum_{i=1}^{n} r_{i j} \sum_{j=1}^{n} r_{i j}}
\end{aligned}
$$

$F L_{i}=$ Sensibility Index of Dispersion;

$B L_{i}=$ Power Index of dispersion;

$r_{i j}=$ The factor of Leontief Inverse Matrix;

$\sum_{j=1}^{n} r_{i j}=$ The sum of columns of Leontief Inverse Matrix;

$\sum_{i=1}^{n} r_{i j}=$ The sum of rows of Leontief Inverse Matrix.

\section{Results}

Table 8 shows the FL effects of the ICT manufacturing industry between Korea and USA during the entire study period from 2006 to 2015.

Table 8 shows the results of linkage effects analysis of ICT manufacturing industry in Korea and the United States. Backward linkage effect of Korean ICT manufacturing industry is 1.24 on average over 10 years, which has a large influence on other industries. On the other hand, that of the US has a small influence at 0.85 . Backward linkage effect represents the influence of an industry on all industries when demand for an industry increase. If backward linkage effect of the ICT manufacturing industry is large, it means that the impact on all industries is large [54,55]. Therefore, it can be said that while Korean 
ICT manufacturing industry has a great influence on all industries in the country, in the US it does not.

Table 8. Comparison of linkage effects of ICT manufacturing between Korea and USA.

\begin{tabular}{ccccc}
\hline \multirow{2}{*}{ Year } & \multicolumn{2}{c}{$\begin{array}{c}\text { Forward Linkage of } \\
\text { ICT Manufacturing }\end{array}$} & \multicolumn{2}{c}{$\begin{array}{c}\text { Backward Linkage of } \\
\text { ICT Manufacturing }\end{array}$} \\
\cline { 2 - 5 } & Korea & USA & Korea & USA \\
\hline 2006 & 1.719 & 0.777 & 1.262 & 0.946 \\
2007 & 1.604 & 0.728 & 1.245 & 0.966 \\
2008 & 1.528 & 0.807 & 1.241 & 0.923 \\
2009 & 1.823 & 0.862 & 1.281 & 0.867 \\
2010 & 1.54 & 0.806 & 1.253 & 0.832 \\
2011 & 1.791 & 0.819 & 1.282 & 0.835 \\
2012 & 1.644 & 0.825 & 1.239 & 0.816 \\
2013 & 1.586 & 0.915 & 1.2 & 0.803 \\
2014 & 1.573 & 0.889 & 1.213 & 0.781 \\
2015 & 1.716 & 1.005 & 1.177 & 0.771 \\
Avg. & 1.652 & 0.843 & 1.239 & 0.854 \\
\hline
\end{tabular}

The forward linkage effect of the Korean ICT manufacturing industry is 1.65 on average over 10 years, which has a great influence on other industries. On the other hand, that of the US has a small influence at 0.84. The large forward linkage effect means that when the demand for products of all industries increases, the influence that an industry will receive is large [54,55]. In other words, the large forward linkage effect of ICT manufacturing industry means that the output of the industry is used as intermediate goods in the production process of other industries. Since this indicator is analyzed from the standpoint of intermediate goods used during the production process of output, it also means dependence on other industries. Therefore, we can say that Korean ICT manufacturing industry plays a large role as a factor of production when producing other industries, but that of the United States is not sufficiently performing such a role. Table 9 shows the results of linkage effects analysis of ICT service industry in Korea and the United States.

Table 9. Comparison of linkage effects of ICT Service between Korea and USA.

\begin{tabular}{ccccc}
\hline \multirow{2}{*}{ Year } & \multicolumn{2}{c}{ Forward Linkage of ICT Service } & \multicolumn{2}{c}{ Backward Linkage of ICT Service } \\
\cline { 2 - 5 } & Korea & USA & Korea & USA \\
\hline 2006 & 1.028 & 0.894 & 0.891 & 0.874 \\
2007 & 1.013 & 0.887 & 0.907 & 0.87 \\
2008 & 0.939 & 0.897 & 0.897 & 0.86 \\
2009 & 0.949 & 0.992 & 0.922 & 0.923 \\
2010 & 0.938 & 0.957 & 0.919 & 0.93 \\
2011 & 0.917 & 0.929 & 0.933 & 0.936 \\
2012 & 0.905 & 0.926 & 0.919 & 0.945 \\
2013 & 0.927 & 0.932 & 0.91 & 0.928 \\
2014 & 0.947 & 0.933 & 0.918 & 0.94 \\
2015 & 0.92 & 0.972 & 0.932 & 0.939 \\
Avg. & 0.948 & 0.932 & 0.915 & 0.915 \\
\hline
\end{tabular}

Backward linkage effect of Korean ICT service industry is 0.91 on average over 10 years, which has a small influence on other industries. That of the United States is also 0.91, which has a small influence. ICT service industries of the two countries have small backward linkage effects, so their influence on other industries is small.

Forward linkage effect of the Korean ICT service industry is 0.95 on average over 10 years, with a small influence on other industries. That of the US is also 0.93, which has a small influence. If the forward linkage effect of ICT service industry is small, it means that even if the demand for other industries increases, the demand for that industry also does 
not increase. In other words, since the dependence on other industries is low, even if the demand of other industries increases, there is little possibility that the relevant industries will be put into the process as a production factor.

Table 10 presents a summary of the statistical test results of the two hypotheses and four sub hypotheses in this study. This study compared ICT manufacturing and service sectors between Korea and USA to the relationship linkage effects. The hypothesis H1 that linkage effects of Korean ICT manufacturing industry and the US are different was accepted. $(p<0.000)$. On the other hand, the hypothesis $\mathrm{H} 2$ that the linkage effects of the ICT service industry in Korea and the US are different was rejected, and the pattern of the linkage effect of ICT service industry between the two countries is drawn as shown in (Figure 1). The result of this study show that ICT manufacturing sectors of Korea and USA have very different linkage effects.

Table 10. Results of hypothesis testing.

\begin{tabular}{clcc}
\hline \multicolumn{1}{c}{ Hypotheses } & $p$-Value & Results \\
\hline $\mathbf{H 1}$ & $\begin{array}{l}\text { The linkage effect between the Korean ICT } \\
\text { manufacturing industry and the US is different. } \\
\text { The backward linkage effect between the Korean ICT } \\
\text { manufacturing industry and the US is different. }\end{array}$ & Accept \\
$\mathbf{H 1 b}$ & $\begin{array}{l}\text { The forward linkage effect between the Korean ICT } \\
\text { manufacturing industry and the US is different. } \\
\text { The linkage effect between the Korean ICT service } \\
\text { industry and the US is different. } \\
\text { The backward linkage effect between the Korean ICT } \\
\mathbf{H 2 a}\end{array}$ & $\begin{array}{l}\text { Service industry and the US is different. } \\
\text { The forward linkage effect between the Korean ICT } \\
\text { service industry and the US is different. }\end{array}$ & Accept \\
$\mathbf{H 2 b}$ & Accept & Reject \\
\hline
\end{tabular}

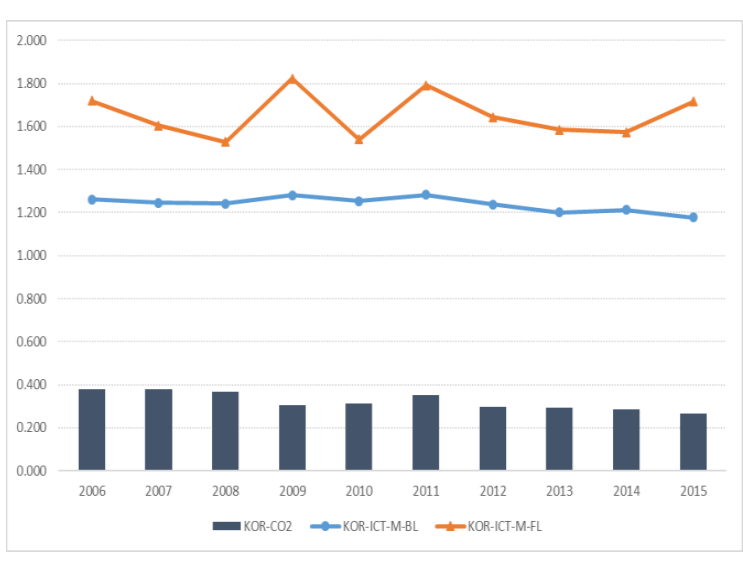

(a)

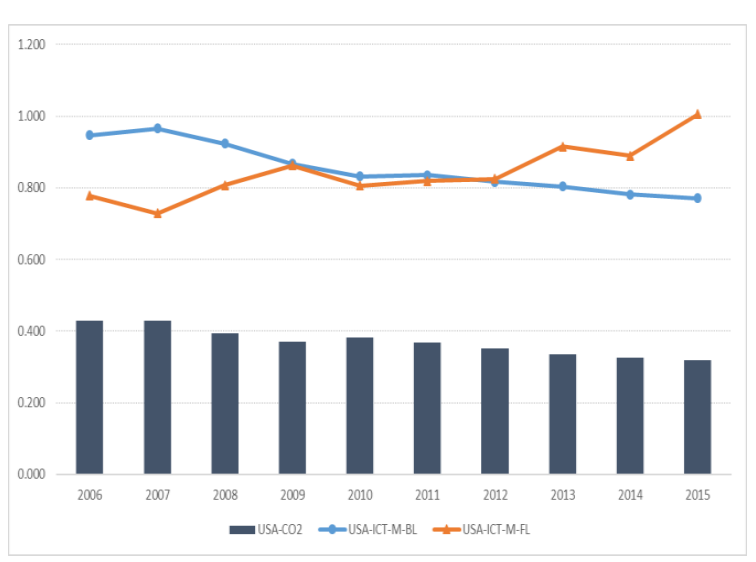

(b)

Figure 1. Trends of linkage effect and $\mathrm{CO}_{2}$ emission of ICT manufacturing between Korea and USA: (a) Korea (2006-2015); (b) USA (2006-2015). Source: authors' own computations on the data collected from OECD stat [45].

$\mathrm{CO}_{2}$ emissions were analyzed along with the linkage effect of ICT industry in Korea and the United States in accordance with the low carbonization trend of major countries in the world.

From 2006 to 2015, ICT manufacturing industry in Korea has an average of $1.9 \mathrm{t}$ of $\mathrm{CO}_{2}$ emissions, accounting for $0.33 \%$ of the total $\mathrm{CO}_{2}$ emissions [45]. As shown in Table 11, $\mathrm{CO}_{2}$ emissions are gradually decreasing from 0.379 in 2006 to 0.267 in 2015. Considering linkage effect in Figure 1, ICT manufacturing industry in Korea has a high relationship with other industries and $\mathrm{CO}_{2}$ emissions are gradually decreasing, so it is the industry suitable for realizing the goal of low carbonization and sustainable economic development. From 2006 to 2015, $\mathrm{CO}_{2}$ emissions in the US are $23.1 \mathrm{t}$, accounting for $0.37 \%$ 
of the total $\mathrm{CO}_{2}$ emissions [45]. In addition, compared to the entire industry, $\mathrm{CO}_{2}$ emissions of ICT manufacturing industry in the US are gradually decreasing from 0.430 in 2006 to 0.319 in 2015. Considering the linkage effect, ICT manufacturing industry in the US is the industry that has a low relationship with other industries and $\mathrm{CO}_{2}$ emissions are gradually decreasing. However, since the linkage effect of ICT manufacturing industry in the US are gradually increasing, it is the industry that can be continuously developed.

Table 11. Comparison of $\mathrm{CO}_{2}$ emission of ICT industry between Korea and USA.

\begin{tabular}{ccccc}
\hline \multirow{2}{*}{ Year } & \multicolumn{4}{c}{ CO $_{\mathbf{2}}$ Emission of ICT Service } \\
\cline { 2 - 5 } & Korea & USA & Korea & USA \\
\hline 2006 & 0.379 & 0.430 & 0.490 & 0.417 \\
2007 & 0.379 & 0.429 & 0.458 & 0.425 \\
2008 & 0.366 & 0.394 & 0.432 & 0.436 \\
2009 & 0.304 & 0.370 & 0.471 & 0.488 \\
2010 & 0.314 & 0.382 & 0.456 & 0.472 \\
2011 & 0.353 & 0.367 & 0.412 & 0.469 \\
2012 & 0.298 & 0.352 & 0.417 & 0.466 \\
2013 & 0.291 & 0.336 & 0.430 & 0.49 \\
2014 & 0.286 & 0.326 & 0.400 & 0.511 \\
2015 & 0.267 & 0.319 & 0.420 & 0.518 \\
Avg. & 0.324 & 0.370 & 0.439 & 0.469 \\
\hline
\end{tabular}

From 2006 to 2015, $\mathrm{CO}_{2}$ emissions from the ICT service industry in Korea average $2.6 \mathrm{t}$, accounting for $0.45 \%$ of the total $\mathrm{CO}_{2}$ emissions [45]. As shown in Table 11, $\mathrm{CO}_{2}$ emissions are gradually decreasing from 0.490 in 2006 to 0.420 in 2015. Considering the linkage effect shown in Figure 2, the ICT service industry in Korea has a small influence on other industries and $\mathrm{CO}_{2}$ emissions are gradually decreasing. Compared with ICT manufacturing industry, ICT service industry has lower linkage effects and higher absolute $\mathrm{CO}_{2}$ emissions than the manufacturing industry. $\mathrm{CO}_{2}$ emissions in the US from 2006 to 2015 are 28.6 tons, accounting for $0.47 \%$ of total $\mathrm{CO}_{2}$ emissions [45]. $\mathrm{CO}_{2}$ emissions of ICT service industry in the US is gradually increasing from 0.417 in 2006 to 0.518 in 2015. Considering the linkage effect in Figure 2, ICT service industry in the US has a low relationship with other industries, but it is the industry that $\mathrm{CO}_{2}$ emissions are gradually increasing. ICT service industry in the US has similar backward and forward linkage effects to the manufacturing industry, but $\mathrm{CO}_{2}$ emissions from its service industry are higher than those from its manufacturing, so efforts to reduce $\mathrm{CO}_{2}$ emissions are needed.

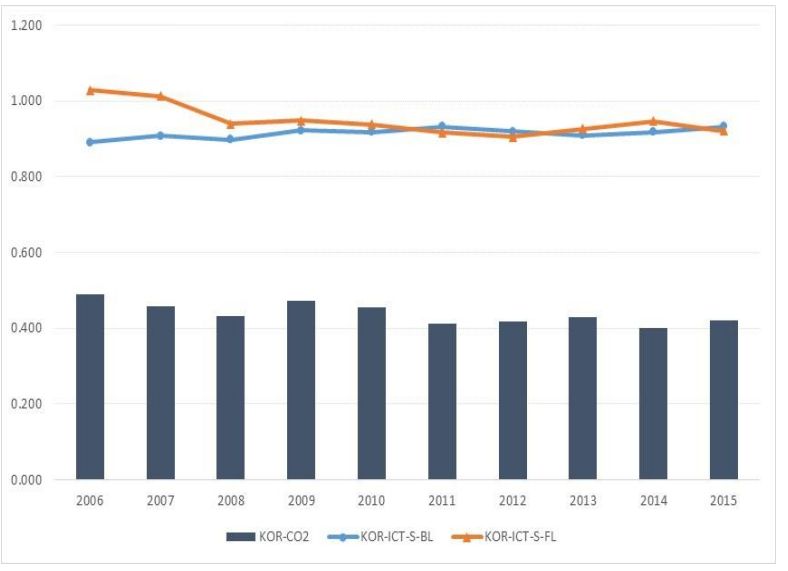

(a)

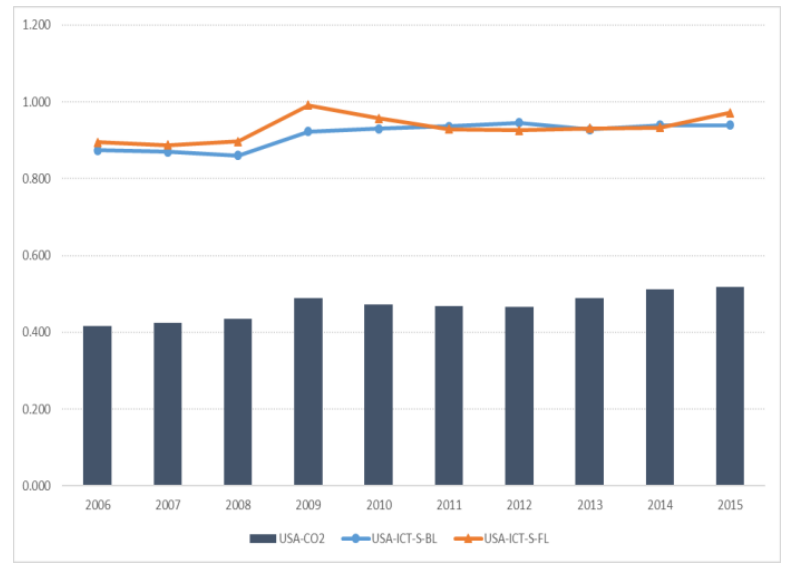

(b)

Figure 2. Trends of linkage effect and $\mathrm{CO}_{2}$ emission of ICT service between Korea and USA: (a) Korea (2006-2015); (b) USA (2006-2015). Source: Authors' own computations on the data collected from OECD stat [45]. 


\section{Discussion and Conclusions}

In this study, we compared ICT manufacturing and service sectors between Korea and USA to analyses the relationship among linkage effects and $\mathrm{CO}_{2}$ emissions. The ICT industry is good for reaching environmentally sound practices because it maintains high productivity while improving overall energy productivity in the national economy. At the same time, due to the ICT, all economic sectors can become more energy efficient. By increasing the energy efficiency, it reduces the environmental impacts of other sectors because ICT allows existing processes to be optimized or enables entirely new, more energy efficient processes [56]. We use data from OECD for the period between 2006 and 2015 and utilized IO analysis and Leontief's Matrix to calculate the backward and forward linkage effects. Additionally, in order to analyze whether $\mathrm{CO}_{2}$ emissions vary according to the final output type, the same industry classification standard used in linkage effects analysis was applied. The results of this study show that the ICT industries sectors of Korea and USA have a few different effects on each national economy.

The finding of this study has important implications for both theory and practice. First, the ICT industry is classified into ICT service and ICT manufacturing industry, and the relationship between linkage effects and $\mathrm{CO}_{2}$ emissions of the two industries is examined in this study, in a complex manner. Existing studies have conducted comparative analysis of linkage effects in all industries $[48,57,58]$ or limited to one country $[37,59,60]$. However, ICT industry has different growth rates and linkage effects depending on the type of final product. Additionally, $\mathrm{CO}_{2}$ emissions are different. Its $\mathrm{CO}_{2}$ emissions can be divided into ICT manufacturing industry, which consumes energy to produce electronic devices, and ICT service industry, which consumes energy to utilize the produced electronic devices. Based on these results, this study is meaningful in analyzing the effects of each industry by dividing it into manufacturing and service sectors according to the type of final product.

Second, ICT service industries in Korea and the US show higher $\mathrm{CO}_{2}$ emissions than their ICT manufacturing industries. This means that the transition from manufacturing to service industry does not unconditionally contribute to the reduction of domestic $\mathrm{CO}_{2}$ emissions. It is thought that the power consumption in ICT industry is relatively small compared to other industries. However, due to the spread of PCs and the increase in the amount of Internet communication, standby power has increased, leading to an increase in power consumption. The ICT industry, which people thought to be the most environmentally friendly, is changing into the industry where $\mathrm{CO}_{2}$ emissions are gradually increasing. However, because ICT technology is also connected with new ones that can quickly solve these environmental problems, the world is investing intensively in ICT. The ICT service industry is expected to be the one that can deplete $\mathrm{CO}_{2}$ emissions by expanding non-face-to-face services and utilizing rapidly developing IT technology [61], but it is also true that its influence on air pollution is gradually increasing. In the case of linkage effects of the service industry, forward and backward linkage effects in both countries are about 0.9 , and the influences on other industries are not significant. Though, in the ICT service industry in the US, $\mathrm{CO}_{2}$ emissions are gradually increasing. In other words, the degree of development with other industries is insignificant, but caution is needed because the amount of ICT industry in the country's total $\mathrm{CO}_{2}$ emissions is increasing. In addition, it is necessary to change the industrial structure through the development of ICT technology so that it can develop together with other industries.

Third, $\mathrm{CO}_{2}$ emissions of ICT manufacturing industries in Korea and the United States are on the decline. This result implies that an increase in manufacturing output by itself does not increase $\mathrm{CO}_{2}$ emissions. It was confirmed that $\mathrm{CO}_{2}$ emissions of ICT manufacturing industry in Korea and the US are on decreasing trends. In the case of Korea, the proportion of ICT manufacturing industry is increasing, but $\mathrm{CO}_{2}$ emissions decrease, indicating that the increase in the manufacturing industry does not affect the increase in $\mathrm{CO}_{2}$ emissions. Rather, it can be regarded as a change in the energy-intensive nature of the manufacturing industry. In other words, if the manufacturing industry continues to pursue low-carbon emissions and high added value, it will become a sustainable indus- 
try. Therefore, government support should be expanded so that the ICT manufacturing industry makes GREEN production processes, and the ICT manufacturing industry should also make continuous efforts to create eco-friendly construction methods. As a result of linkage effect analysis, it was found that both BL and FL in Korea exceeded 1 and had a lot of influence on other industries, but in the US, both BL and FL were analyzed to be less than 1 . That is, the ICT manufacturing industry in Korea has a significant influence on both forward and backward industries, but the US does not. The ICT manufacturing industry in Korea is their flagship industry, accounting for about 10\% of total production (2018), $6.7 \%$ of GDP ('2019), and exports of USD 94 billion (2019) [62]. ICT manufacturing industry in Korea continues to create investment and employment as the industry leading the national economy despite the recent decline in competitiveness of traditional manufacturing industries such as steel industry and shipbuilding.

Finally, when examining ICT industries of Korea and the US by dividing them into manufacturing and service industries in this study, it is found that that $\mathrm{CO}_{2}$ emissions of all Korean industries increases but decreases in the case of ICT industry. Additionally, as its linkage effects are large, it can be seen that sustainable development based on low carbon is possible. The high linkage effects mean that ICT industry carries out production activities and buys or sells a lot of goods and services from other industries. In this way, the ICT industry in Korea can be said to be the central industry of the national economy because it arouses the supply and demand of other industries and leads to the production activities of that industry. Continued development of this industry will entail the development of new technologies that can reduce the ever-increasing $\mathrm{CO}_{2}$ emissions through increasing government investment. In the case of the United States, $\mathrm{CO}_{2}$ emissions from ICT manufacturing industry are on the decline, but ICT service is on the rise. Additionally, linkage effects are less than 1, indicating that the influence on other industries was insignificant. However, being low does not mean that it has a small share of the total output in the national economy. The linkage effects are only a measure of their influence on other industries, not how much of an industry's output accounts for a country's total output. Actually, the United States is the global number one powerhouse in the ICT industry, has a great added value creation effect, and is easy to converge and combine with other industries. These results suggest that the industry should be accompanied by efforts to reduce $\mathrm{CO}_{2}$ emissions when it develops. Unlike other industries, ICT industry is widely applied in other fields and has the characteristics that it can improve the efficiency of industries and technologies. In the short term, the development of ICT industry can increase energy consumption but in the long term, it is possible to control energy consumption and reduce $\mathrm{CO}_{2}$ emissions by applying ICT technology to energy demand management monitoring and low-carbon optimization. The US government should invest in technology development in ICT industry for it. This is because the development of ICT industry is that of technologies and devices for other industries.

ICT industry is a representative industry that has a comparative advantage over other countries in both Korea and the United States and has a large growth effect compared to investment $[57,63,64]$. When the growth of the ICT industry is combined with the effect of converting energy consumption, systematic support from government for the ICT industry should continue because the effect of reducing $\mathrm{CO}_{2}$ emissions is large.

Despite these implications, this study has the following limitations. First, this study compares and analyzes only two countries in ICT industry, Korea and the United States. Future research should analyze countries that are importantly fostering the ICT industry. Second, this study only analyzed a part of the ICT sectors in Korea and USA because of limitation of publicly available data. Lastly, only the backward linkage effect and forward linkage effect were considered in the analysis of linkage effect without net multipliers. In future studies, additional analysis indicators such as employment inducement effect and value-added inducement effect including net multipliers should be examined together. 
Author Contributions: Conceptualization, J.M. and E.Y.; methodology, J.M. and E.Y.; software, J.M.; validation, E.Y.; formal analysis, J.M.; investigation, H.C.; writing—original draft preparation, J.M.; writing-review and editing, J.M. and E.Y.; supervision, H.C. All authors have read and agreed to the published version of the manuscript.

Funding: This research received no external funding.

Institutional Review Board Statement: Not applicable.

Informed Consent Statement: Not applicable.

Data Availability Statement: Not applicable.

Conflicts of Interest: The authors declare no conflict of interest.

\section{References}

1. Ministry of Environment. Available online: http://www.me.go.kr/home/web/board/read.do?menuId=286\&boardMasterId= 1\&boardCategoryId=39\&boardId=1062250 (accessed on 2 March 2021).

2. European Commission. Communication from the Commission: The European Green Deal; European Commission: Brussels, Belgium, 2019.

3. Eunjoo, H.; Yun Hyeok, C.; Jong Dae, K. Study on Priorities of Regional Climate Change Policy. J. Environ. Sci. Int. 2016, 25, 589-601.

4. Hyun, K.; Sang Gun, L. A comparative study on production inducement effects in key industries of Korea and the Netherlands. Glob. Bus. Financ. Rev. 2020, 25, 13-32.

5. OECD. OECD Digital Economy Outlook 2017; OECD: Paris, France, 2017.

6. OECD. OECD Digital Economy Outlook 2015; OECD: Paris, France, 2015.

7. World Bank. World Bank Annual Report 2017; World Bank Group: Washington, DC, USA, 2017.

8. Ericsson. A Quick Guide to Your Digital Carbon Footprint; Ericsson: Stockholm, Sweden, 2020.

9. Belkhir, L.; Elmeligi, A. Assessing ICT global emissions footprint: Trends to 2040 \& recommendations. J. Clean. Prod. 2018, 177, 448-463.

10. Forbes. Top 100 Digital Companies. 2019. Available online: https://www.forbes.com/top-digital-companies/list/\#tab:rank (accessed on 15 February 2021).

11. OECD. Measuring the Information Economy. E-Commerce; OECD: Paris, France, 2002.

12. OECD. Information Economy—Sector Definitions Based on the International Standard Industry Classification (ISIC 4); OECD: Paris, France, 2007.

13. OECD. OECD Guide to Measuring the Information Society 2011; OECD: Paris, France, 2011.

14. Xing, W.; Ye, X.; Kui, L. Measuring convergence of China's ICT industry: An input-output analysis. Telecommun. Policy 2011, 35, 301-313. [CrossRef]

15. Rohman, I.K. The globalization and stagnation of the ICT sectors in European countries: An input-output analysis. Telecommun. Policy 2013, 37, 387-399. [CrossRef]

16. Hong, J.P.; Byun, J.E.; Kim, P.R. Structural changes and growth factors of the ICT industry in Korea: 1995-2009. Telecommun. Policy 2016, 40, 502-513. [CrossRef]

17. Abubakar, Y.A.; Mitra, J. Innovation performance in European regions: Comparing manufacturing and services ICT subsectors. Int. J. Entrep. Innov. Manag. 2010, 11, 156-177. [CrossRef]

18. GSM Association. The Mobile Economy 2020; GSM Association: London, UK, 2020.

19. Gartner. Gartner Forecasts Worldwide Public Cloud Revenue to Grow 17\% in 2020; Gartner: Stanford, CT, USA, 2019.

20. Canalys. Cloud Infrastructure Spend Reaches US\$20 Billion in Q2 2018, with Hybrid IT Approach Dominant; Canalys: Singapore, 2018.

21. IDC. Semiannual Public Cloud Services Tracker; IDC: Needham, MA, USA, 2018.

22. European Commission. The 2019 EU Industrial RED Investment Scoreboard; European Commission: Luxembourg, 2019.

23. Bieser, J.; Hilty, L. Assessing Indirect Environmental Effects of Information and Communication Technology (ICT): A Systematic Literature Review. Sustainability 2018, 10, 2662. [CrossRef]

24. European Commission. The 2018 EU Industrial RED Investment Scoreboard; European Commission: Luxembourg, 2018.

25. Executive Office of the President. The President's Climate Action Plan; Executive Office of the President: Washington, DC, USA, 2013

26. Oliner, S.D.; Sichel, D.E. The resurgence of growth in the late 1990s: Is information technology the story? J. Econ. Perspect. 2000, 14, 3-22. [CrossRef]

27. García-Muñiz, A.S.; Vicente, M.R. ICT technologies in Europe: A study of technological diffusion and economic growth under network theory. Telecommun. Policy 2014, 38, 360-370. [CrossRef]

28. Fernandez-deGuevara, J.; Lopez-Cobo, M.; Mas, M. The 2017 PREDICT Key Facts Report. An Analysis of ICT RED in the EU and beyond; Joint Research Centre (Seville Site): Luxembourg, 2017.

29. OECD. Measuring the Digital Transformation: A Roadmap for the Future; OECD: Paris, France, 2019. 
30. Mattioli, E.; Lamonica, G.R. The ICT role in the world economy: An input-output analysis. J. World Econ. Res. 2013,2 , $20-25$. [CrossRef]

31. Inklaar, R.; O'Mahony, M.; Timmer, M. ICT and Europe's productivity performance: Industry-level growth account comparisons with the United States. Rev. Income Wealth 2005, 51, 505-536. [CrossRef]

32. Irawan, T. ICT and economic development: Comparing ASEAN member states. Int. Econ. Policy 2014, 11, 97-114. [CrossRef]

33. Malmodin, J.; Lundén, D. The energy and carbon footprint of the global ICT and E\&M sectors 2010-2015. Sustainability 2018, $10,3027$.

34. Talib, F.; Rahman, Z.; Akhtar, A. An instrument for measuring the key practices of total quality management in ICT industry: An empirical study in India. Serv. Bus. 2013, 7, 275-306. [CrossRef]

35. Aasa, L.; Adrian, M. The Effect of Energy Efficiency on Swedish Carbon Dioxide Emissions 1993-2004; Gothenburg University: Goeteborg, Sweden, 2008.

36. Zhou, P.; Ang, B.W.; Poh, K.L. Slacks-based efficiency measures for modeling environmental performance. Ecol. Econ. 2006, 60, 111-118. [CrossRef]

37. Moon, J.; Yun, E.; Lee, J. Identifying the Sustainable Industry by Input-Output Analysis Combined with $\mathrm{CO}_{2}$ Emissions: A Time Series Study from 2005 to 2015 in South Korea. Sustainability 2020, 12, 6043. [CrossRef]

38. Lee, S.; Noh, D.-W.; Oh, D.-H. Characterizing the difference between indirect and direct $\mathrm{CO}_{2}$ emissions: Evidence from Korean manufacturing industries, 2004-2010. Sustainability 2018, 10, 2711. [CrossRef]

39. Jaeger, C.C.; Paroussos, L.; Kupers, R.T.L.; Mangalagiu, D. A New Growth Path for Europe: Generating Prosperity and Jobs in the Low-Carbon Economy; Synthesis Report PIK; University of Oxford: Oxford, UK, 2011.

40. Chaminade, C.; Plechero, M. Do regions make a difference? Regional innovation systems and global innovation networks in the ICT industry. Eur. Plan. Stud. 2015, 23, 215-237. [CrossRef]

41. Halkos, G.E.; Tzeremes, N.G. International competitiveness in the ICT industry: Evaluating the performance of the top 50 companies. Glob. Econ. Rev. 2007, 36, 167-182. [CrossRef]

42. Lee, D.H.; Hong, G.Y.; Lee, S.-G. The relationship among competitive advantage, catch-up, and linkage effects: A comparative study on ICT industry between South Korea and India. Serv. Bus. 2019, 13, 603-624. [CrossRef]

43. Lechman, E.; Marszk, A. ICT technologies and financial innovations: The case of exchange traded funds in Brazil, Japan, Mexico, South Korea and the United States. Technol. Forecast. Soc. Chang. 2015, 99, 355-376. [CrossRef]

44. Rhee, K.H.; Pyo, H.K. Aggregate Total Factor Productivity and Resource Reallocation Effect of ICT Sectors in Korea: A Comparison with the USA, Japan and EU7. Korean Econ. Rev. 2012, 28, 189-219.

45. OECD. OECD Stat; OECD: Paris, France, 2020.

46. Hirschman, A.O. The Strategy of Economic Development; Yale University Press: New Haven, CT, USA, 1958.

47. Ye, Z.P.; Yin, Y.P. Economic Linkages and Comparative Advantage of the UK Creative Sector. University of Hertfordshire Business School Working Paper No. UHBS, 2. Available online: https:/ / papers.ssrn.com/sol3/papers.cfm?abstract_id=1310948 (accessed on 16 February 2021).

48. Chiu, R.-H.; Lin, Y.-C. Applying input-output model to investigate the inter-industrial linkage of transportation industry in Taiwan. J. Mar. Sci. Technol. 2012, 20, 173.

49. Sari, K.; Arifin, M. The linkage among technology-intensive manufacture industries in east java by input-output analysis approach. J. ST Policy RD Manag. 2014, 12, 45-54.

50. Morrissey, K.; O'Donoghue, C. The role of the marine sector in the Irish national economy: An input-output analysis. Mar. Policy 2013, 37, 230-238. [CrossRef]

51. Leontiew, W. The structure of American economy, 1919-1929. In An Empirical Application of Equilibrium Analysis; Harvard University Press: Cambridge, MA, USA, 1941.

52. Rasmussen, P.N. Studies in Inter-Sectoral Relations; Einar Harcks: København, Denmark, 1956.

53. Lin, S.J.; Chang, Y.F. Linkage effects and environmental impacts from oil consumption industries in Taiwan. J. Environ. Manag. 1997, 49, 393-411. [CrossRef]

54. Chang, Y.-T.; Shin, S.-H.; Lee, P.T.-W. Economic impact of port sectors on South African economy: An input-output analysis. Transp. Policy 2014, 35, 333-340. [CrossRef]

55. Kwak, S.-J.; Yoo, S.-H.; Chang, J.-I. The role of the maritime industry in the Korean national economy: An input-output analysis. Mar. Policy 2005, 29, 371-383. [CrossRef]

56. Ozturk, A.; Umit, K.; Medeni, I.T.; Ucuncu, B.; Caylan, M.; Akba, F.; Medeni, T.D. Green ICT (Information and Communication Technologies): A review of academic and practitioner perspectives. Int. J. eBus. eGov. Stud. 2011, 3, 1-16.

57. Han, I.; Byun, S.-Y.; Shin, W.S. A comparative study of factors associated with technology-enabled learning between the United States and South Korea. Educ. Technol. Res. Dev. 2018, 66, 1303-1320. [CrossRef]

58. Jeong, K.; Hong, T.; Kim, J. Development of a $\mathrm{CO}_{2}$ emission benchmark for achieving the national $\mathrm{CO}_{2}$ emission reduction target by 2030. Energy Build. 2018, 158, 86-94. [CrossRef]

59. Hwang, W.-S.; Shin, J. ICT-specific technological change and economic growth in Korea. Telecommun. Policy 2017, 41, 282-294. [CrossRef]

60. Zheng, H.; Fang, Q.; Wang, C.; Wang, H.; Ren, R. China's carbon footprint based on input-output table series: 1992-2020. Sustainability 2017, 9, 387. [CrossRef] 
61. Faisal, F.; Turgut Tursoy, A.; Pervaiz, R. Does ICT lessen $\mathrm{CO}_{2}$ emissions for fast-emerging economies? An application of the heterogeneous panel estimations. Environ. Sci. Pollut. Res 2020, 27, 10778-10789. [CrossRef] [PubMed]

62. KOSIS. Kostat. 2019. Available online: http://kostat.go.kr/portal/korea/index.action (accessed on 28 December 2020).

63. Kim, J.; Eunnyeong, H. Effect of ICT capital on the demands for labor and energy in major industries of Korea, US, and UK. Environ. Resour. Econ. Rev. 2014, 23, 91-132. [CrossRef]

64. Min, Y.-K.; Lee, S.-G.; Aoshima, Y. A comparative study on industrial spillover effects among Korea, China, the USA, Germany and Japan. Ind. Manag. Data Syst. 2019, 119, 454-472. [CrossRef] 